\title{
Dietary antioxidant capacity of the patients with cardiovascular disease in a cross-sectional study
}

\author{
Małgorzata E Zujko ${ }^{1 *}$, Anna M Witkowska', Anna Waśkiewicz², Walerian Piotrowski and Katarzyna M Terlikowska ${ }^{1}$
}

\begin{abstract}
Background: The purpose of this study was to establish sources and patterns of antioxidant, polyphenol and flavonoid intakes in men and women with cardiovascular disease (CVD).

Methods: The subjects with CVD and healthy controls $(\mathrm{HC})$ were participants of the Polish National Multicenter Health Survey (WOBASZ). Food intakes were measured with the 1-day 24-hour recall method. A self-developed database was used to calculate dietary total antioxidant capacity (DTAC), dietary total polyphenol content (DTPC) and dietary total flavonoid content (DTFC).

Results: DTAC did not differ between the men with CVD and HC men (6442 vs. $6066 \mu$ mol trolox equivalents - TE), but in the women with CVD it was significantly higher than in the HC women (6182 vs. $5500 \mu \mathrm{mol}$ TE). The main sources of antioxidants in the males with CVD were: tea, coffee, apples, and nuts and seeds, and tea, coffee and apples in HC. In the females they were: tea, coffee, apples and strawberries, both in the women with CVD and HC. DTPC in the men with CVD did not differ from HC (1198 vs. $1114 \mathrm{mg}$ gallic acid equivalents, GAE). In the females, DTPC was significantly higher in the subjects with CVD as compared to HC (1075 vs. $981 \mathrm{mg}$ GAE). Predominant sources of polyphenols were: tea, coffee, cabbage, potatoes, apples and white bread in the men with CVD, and tea, coffee, potatoes, white bread and apples in HC, while in the women (both with CVD and HC): tea, coffee, apples, potatoes and cabbage. No differences in DTFC have been found between the males with CVD and HC (212 vs. 202 mg quercetine equivalents, QE). In the women with CVD, DTFC was significantly higher than in HC (200 vs. 177 mg QE). Main sources of flavonoids in all participants (men and women, CVD and HC) were tea, apples, cabbage and coffee.

Conclusions: Polish men and women faced with CVD beneficially modify their dietary practices by enhancing intakes of foods that are sources of antioxidants, polyphenols and flavonoids. Different sources and patterns of antioxidant, polyphenol and flavonoid intakes, however, between male and female patients with CVD were observed.
\end{abstract}

Keywords: Cardiovascular disease, Diet, Antioxidant capacity, Polyphenols, Flavonoids

\section{Background}

Cardiovascular disease (CVD) is one of the most common causes of death worldwide, with pathogenesis in which multiple fixed (age, gender, genotype, menopausal status) and modifiable factors (diet, exercise, stress, smoking and ethanol consumption) are involved [1]. Among the modifiable lifestyle-related factors the main role plays a diet [2]. Epidemiological studies found an inverse association between the intake of antioxidant-rich food and the

\footnotetext{
*Correspondence: malgorzata.zujko@umb.edu.pl

${ }^{1}$ Department of Food Commodities Science and Technology, Medical

University, Szpitalna 37, Bialystok 15-295, Poland

Full list of author information is available at the end of the article
}

risk of CVD $[3,4]$. Dietary antioxidants such as vitamin E, vitamin $C$, carotenoids and polyphenols have protective cardiovascular effect through suppressing oxidative stress, defined as an imbalance between production of reactive oxygen (ROS) and nitrogen species (RNS), and antioxidants (endo- and exogenous). Adverse effects of free radical (FR) overproduction on cardiovascular system are associated with endothelial dysfunction mediated through nitric oxide (NO) degradation, lipid peroxidation and inflammatory response. Antioxidants can donate electrons to FR molecules, that contain one or more unpaired electrons, blocking by this deleterious chain reactions [5]. 
Polyphenols which are derived mostly from plant foods, are widely distributed in the human diet. Dietary total polyphenol intake could be as high as $1 \mathrm{~g} / \mathrm{d}$, which is much higher than all other classes of phytochemicals and known dietary antioxidants e.g. antioxidant vitamins [6]. The major class of polyphenols are flavonoids. Several in vitro and in vivo studies have suggested that dietary flavonoids, which are mainly found in fruits and vegetables, may induct an antioxidant defense system and exert beneficial effects on the vascular system via an improving endothelial function and inhibiting low density lipoprotein oxidation $[7,8]$.

Adequate nutrition, which supplies appropriate ratios of antioxidants, plays important role in the CVD prevention and can improve symptoms of the disease. Therefore, the purpose of this study was to estimate dietary total antioxidant capacity (DTAC), dietary total polyphenol (DTPC) and flavonoid contents (DTFC) in the diet of the CVD patients, and to establish main dietary patterns of antioxidants. To our knowledge this is the first attempt to estimate antioxidants in a cross-sectional Polish study, which involves a representative sample of CVD patients.

\section{Methods}

\section{Subjects and food consumption}

Subjects were participants of the Polish National Multicenter Health Survey (WOBASZ), which was carried out by the National Institute of Cardiology in Warsaw, Poland, in cooperation with five Polish medical universities. The WOBASZ study was approved by the Bioethics Committee of the National Institute of Cardiology in Warsaw (no 708). This study was continued for 3 years, from January 2003 to December 2005, and included a representative random sample of the general Polish population. The rationale, design, and methods of the cross-sectional study have been described in detail elsewhere [9-11].

A sample of 19,200 individuals (men and women) from the general population of more than 26 million Polish inhabitants aged 20-74 years was randomly selected. Two small (up to 8 thousand inhabitants), 2 medium (8-40 thousand inhabitants), and 2 large communes (above 40 thousands inhabitants) from each of the sixteen Polish provinces were randomly selected. One hundred men and 100 women from each commune, were randomly chosen from the personal identification number (PESEL) database. Finally, 13545 people (6392 men and 7153 women) agreed to take part in the study. Of these, approx. 50\% was randomly selected for nutrition study. Lastly, from 6661 adults (3132 males and 3529 females) 1-day 24-hour dietary recalls (1-d 24-h DR) were collected. The interviewers were trained by a qualified nutritionist specialized in performing nutrition surveys.
Approx. $10 \%$ of the studied sample, 643 subjects (357 men and 286 women), have been previously diagnosed by a cardiologist and hospitalized for CVD (heart attack, heart failure, stroke, heart defects, cardiac arrhythmia, coronary angioplasty or coronary artery bypass, heart pacemaker). This information was provided from selfreported health status questionnaires. Subjects could report more than one disease. A control group with no diagnosed CVD was randomly chosen from 6661 adults by a propensity score matching (PSM) technique, based on matching characteristics: age, body mass index (BMI), cigarette smoking, physical activity, commune type, marital status, level of education, household per-capita income, self-rated health. Scheme of the study and subjects' selection procedure are presented in Figure 1. Baseline characteristics of the participants are shown in Table 1.

The survey was conducted individually in men and women due to gender differences in burden of CVD, which include prevalence of hypertension, diabetes mellitus, metabolic syndrome and lifestyle factors [12].

Each participant was informed about the screening procedures and signed the agreement form. A standardized questionnaire was designed for data collection, which was suitable for the objectives of the study. The respondents were questioned about social, demographic, and economic status, physical activity, smoking, cardiovascular disease, diabetes, health awareness, health care, any ongoing medical treatments. Additionally, the height and weight of each patient were measured and the body mass index (BMI) was calculated according to the formula: $\mathrm{BMI}=\operatorname{weight}(\mathrm{kg}) /$ height $(\mathrm{m})^{2}$. Blood pressure measurements were taken three times on the right arm after 5 minutes of rest in a sitting position in one minute intervals and a final value was calculated as an average measurement. Biochemical tests: total cholesterol, highdensity lipoprotein (HDL), triglycerides and fasting glucose, were performed at the Central Laboratory of the National Institute of Cardiology in Warsaw.

\section{Procedure of food extraction}

Food products were randomly purchased in triplicate at different Polish food markets. Edible raw parts of foods were dried and pulverized in a grinder. Samples $(0.25 \mathrm{~g})$ were placed in test tubes with $10 \mathrm{ml}$ of methanol/water solution $(50: 50, \mathrm{v} / \mathrm{v})$ and the $\mathrm{pH}$ was adjusted to 2 using $2 \mathrm{M} \mathrm{HCl}$. The tubes were thoroughly shaken at room temperature for 1 hour and then centrifuged at $4000 \mathrm{~g}$ for $10 \mathrm{~min}$ in a centrifuge (MPW-350e, Poland). The resulting supernatants were collected in clean dry test tubes. Then the residues were extracted with $10 \mathrm{ml}$ of an acetone/water mixture (70/30, v/v) and the procedure was repeated. Both methanol and acetone extracts were combined and used for analyses. Samples of tea, coffee, 


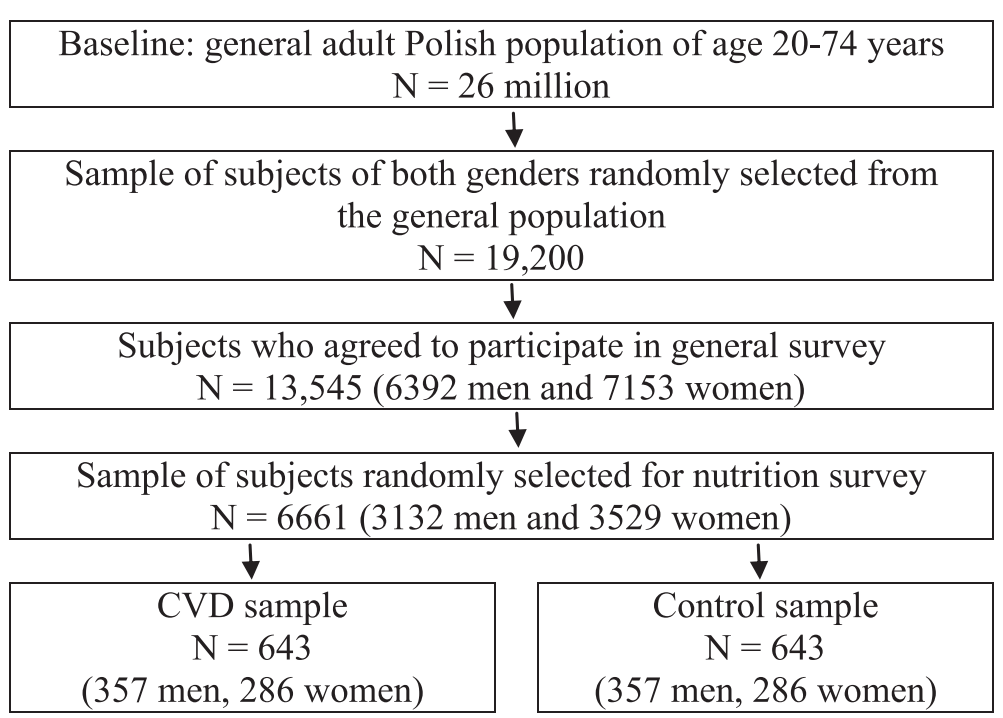

Figure 1 Scheme of the study and subjects' selection procedure.

drinking chocolate and hot cocoa were extracted with water (1 g sample per $100 \mathrm{ml}$ boiling distilled water).

\section{Procedure of FRAP assay}

Ferric Reducing Antioxidant Power (FRAP) was determined according to Benzie and Strain [13]. A $1.5 \mathrm{ml}$ of 2,4,6-tripyridyl-s-triazine solution was warmed to $37^{\circ} \mathrm{C}$; then a reagent blank was measured at $593 \mathrm{~nm}$. Subsequently, $50 \mu \mathrm{l}$ of the sample, dissolved in distilled water (1:4), was added to the FRAP reagent. The absorbance was measured following incubation at $37^{\circ} \mathrm{C}$ for $4 \mathrm{~min}$. The antioxidant potential of samples was determined from the standard curve and expressed as trolox equivalents (mmol TE/100 $\mathrm{g}$ fresh edible mass of plant foods or $100 \mathrm{ml}$ of beverage).

\section{Procedure of total polyphenol assay}

Total polyphenol contents in food products were determined using a Singleton and Rossi method [14]. Samples $(0.2 \mathrm{ml})$ were mixed with a $1 \mathrm{ml}$ Folin-Ciocalteau reagent previously diluted in distilled water $(1: 10)$ and $0.8 \mathrm{ml}$ of $7.5 \%(\mathrm{w} / \mathrm{v})$ sodium carbonate. The absorbance was measured after $30 \mathrm{~min}$ at $765 \mathrm{~nm}$. The results were expressed as gallic acid equivalents (GAE) in mg total polyphenols on $100 \mathrm{~g}$ fresh edible mass of plant foods or $100 \mathrm{ml}$ of beverages.

\section{Procedure of total flavonoid assay}

Total flavonoid content in food samples was determined according to Arvouet-Grand et al. [15]. Briefly, $1 \mathrm{ml}$ of $2 \%$ aluminium trichloride $\left(\mathrm{AlCl}_{3}\right)$ in methanol was mixed with the same volume of the extract. A yellow color indicated the presence of flavonoids. Absorption readings at
$415 \mathrm{~nm}$ were taken after 10 min against a blank sample consisting of a $1 \mathrm{ml}$ extract solution with $1 \mathrm{ml}$ methanol without $\mathrm{AlCl}_{3}$. The concentration of total flavonoids in samples was determined from the standard curve and expressed as quercetin equivalents (mg QE/100 g fresh mass of plant foods or $100 \mathrm{ml}$ of beverage).

\section{Assessment of total polyphenols and flavonoids intake, and antioxidant capacity of diet}

Previously published [16-19] self-developed dietary database of the total antioxidant capacity of foods, determined by the FRAP method, as well as total polyphenols and flavonoids in plant food items was used to calculate dietary total antioxidant capacity (DTAC), dietary total polyphenol content (DTPC) and dietary total flavonoid content (DTFC). This database contains over 150 national foods and food products classified into 6 categories ( 1 - beverages; 2 - vegetables; 3 - fruits and jams; 4 bread, rolls and cereals products; 5 - chocolates; 6 - nuts and seeds) of which 84 plant foods were found to be consumed by the participants. DTAC was expressed as $\mu \mathrm{mol}$ trolox equivalents (TE), DTPC - as mg gallic acid equivalents (GAE) and DTFC - as mg quercetine equivalents $(\mathrm{QE})$.

\section{Statistical analysis}

Statistical analyses were performed using SAS software (version 9.2; Cary, NC, USA). The results were expressed as number, percentage, mean value and standard deviation or $95 \%$ confidence interval, median and $25-75 \%$ percentiles. Categorical variables were compared with the chi-square test. Normality of continuous data distribution was verified with the Shapiro-Wilk test. To 
Table 1 Baseline characteristics of the participants

\begin{tabular}{|c|c|c|c|c|c|c|}
\hline \multirow[t]{2}{*}{ Characteristics } & \multicolumn{3}{|l|}{ Men } & \multicolumn{3}{|l|}{ Women } \\
\hline & CVD patients & Healthy control & $\mathrm{p}$ & CVD patients & Healthy control & $\mathrm{p}$ \\
\hline Number & 357 & 357 & - & 286 & 286 & - \\
\hline \multicolumn{7}{|l|}{ Number of CVD types ${ }^{a}$} \\
\hline Heart attack & 170 & - & - & 82 & - & - \\
\hline Heart failure & 138 & - & - & 116 & - & - \\
\hline Stroke & 44 & - & - & 22 & - & - \\
\hline Heart defects & 103 & - & - & 94 & - & - \\
\hline Cardiac arrhythmia & 169 & - & - & 171 & - & - \\
\hline Coronary angioplasty or bypass & 43 & - & - & 7 & - & - \\
\hline Heart pacemaker & 7 & - & - & 3 & - & - \\
\hline Age (years) & $57.2 \pm 11.8$ & $57.0 \pm 11.8$ & 0.82 & $57.5 \pm 12.0$ & $57.1 \pm 12.4$ & 0.70 \\
\hline $\mathrm{BMI}\left(\mathrm{kg} / \mathrm{m}^{2}\right)$ & $27.8 \pm 4.9$ & $27.8 \pm 4.7$ & 0.92 & $29.1 \pm 5.9$ & $28.8 \pm 6.3$ & 0.56 \\
\hline Hypertension ${ }^{b}(\%)$ & 64.7 & 56.6 & 0.03 & 64.0 & 54.2 & 0.02 \\
\hline Hypercholesterolemia $^{c}(\%)$ & 71.5 & 74.6 & 0.36 & 72.1 & 77.0 & 0.19 \\
\hline Total cholesterol (mmol/l) & $5.44 \pm 1.15$ & $5.61 \pm 1.14$ & 0.05 & $5.54 \pm 1.14$ & $5.72 \pm 1.13$ & 0.06 \\
\hline $\mathrm{HDL}(\mathrm{mmol} / \mathrm{l})$ & $1.26 \pm 0.36$ & $1.35 \pm 0.42$ & 0.01 & $1.42 \pm 0.37$ & $1.50 \pm 0.40$ & 0.02 \\
\hline Triglycerides (mmol/l) & $1.68 \pm 1.04$ & $1.76 \pm 1.31$ & 0.42 & $1.67 \pm 1.24$ & $1.61 \pm 1.66$ & 0.66 \\
\hline Diabetes $^{\mathrm{d}}(\%)$ & 16.4 & 12.0 & 0.09 & 16.6 & 11.1 & 0.06 \\
\hline Smoking (\%) & & & 0.02 & & & 0.15 \\
\hline Non-smokers & 24.4 & 30.5 & & 65.0 & 62.9 & \\
\hline Former smokers & 47.6 & 37.0 & & 22.0 & 18.5 & \\
\hline Current smokers & 28.0 & 32.5 & & 12.9 & 18.5 & \\
\hline Physical activity (\%) & & & 0.94 & & & 0.09 \\
\hline Low level & 44.5 & 45.1 & & 59.4 & 55.9 & \\
\hline Middle level & 12.0 & 11.2 & & 6.6 & 11.9 & \\
\hline High level & 43.4 & 43.7 & & 33.9 & 32.2 & \\
\hline Commune type (\%) & & & 0.78 & & & 0.59 \\
\hline$<8$ thousand inhabitants & 30.5 & 31.7 & & 32.5 & 33.2 & \\
\hline 8-40 thousand inhabitants & 37.3 & 34.7 & & 37.1 & 33.2 & \\
\hline$>40$ thousand inhabitants & 32.2 & 33.6 & & 30.4 & 33.6 & \\
\hline Marital status (\%) & & & 0.02 & & & 0.22 \\
\hline Married & 86.3 & 79.8 & & 67.8 & 62.9 & \\
\hline Single & 13.7 & 20.2 & & 32.2 & 37.1 & \\
\hline Level of education (\%) & & & 0.74 & & & 0.16 \\
\hline Under middle & 66.1 & 66.4 & & 62.9 & 65.4 & \\
\hline Middle & 25.8 & 24.1 & & 29.0 & 30.4 & \\
\hline Higher & 8.1 & 9.5 & & 8.0 & 4.2 & \\
\hline Household per-capita income (\%) & & & 0.03 & & & 0.82 \\
\hline Low & 36.7 & 42.9 & & 47.5 & 46.1 & \\
\hline Middle & 42.3 & 31.6 & & 38.5 & 39.9 & \\
\hline High & 11.2 & 13.7 & & 6.3 & 7.7 & \\
\hline Not stated & 9.8 & 11.8 & & 7.7 & 6.3 & \\
\hline
\end{tabular}


Table 1 Baseline characteristics of the participants (Continued)

\begin{tabular}{llccc}
\hline Self-rated health (\%) & & 0.69 & & \\
Bad, average & 65.8 & 64.4 & 74.5 & 76.2 \\
Good, very good & 34.2 & 35.6 & 25.5 & 23.8 \\
\hline
\end{tabular}

${ }^{\mathrm{a}}$ Patients could indicate more than one disease, ${ }^{\mathrm{b}}$ Hypertension: systolic blood pressure $\geq 140 \mathrm{mmHg}$ or diastolic blood pressure $\geq 90 \mathrm{mmHg}$ or treatment in interview, ${ }^{C}$ Hypercholesterolemia: total cholesterol $\geq 5 \mathrm{mmol} / \mathrm{l}$ or treatment in interview, ${ }^{\mathrm{d} D i a b e t e s: ~ f a s t i n g ~ g l u c o s e ~} \geq 7 \mathrm{mmol} / \mathrm{l}$ or treatment in interview, BMI - Body Mass Index, CVD - cardiovascular disease, HDL - high-density lipoprotein.

compare the quantitative variables with normal distribution the $t$ test was used, and for nonnormal distribution the Mann-Whitney-Wilcoxon nonparametric test was applied. P-values of less than 0.05 were considered statistically significant.

\section{Results}

Baseline characteristics of the participants are shown in Table 1. Compared to the healthy control (HC), hypertension was significantly frequent, both in men and women with CVD. Among biochemical parameters serum HDL levels were found lower in CVD patients (both men and women) in comparison to HC. Among lifestyle variables, significant influences were observed for smoking, marital status and household per-capita income in the CVD and HC men.

Daily intakes of plant foods and beverages by the participants are shown in Table 2. Among beverages, consumption of tea and coffee was predominant, with $67-69 \%$ and $20-28 \%$ contribution, respectively, in all studied groups (Table 3). The men presented 29\% higher consumption of vegetables, but $40 \%$ lower fruit and fruit jam intake in comparison to the women. Moreover, the women with CVD consumed significantly higher amounts of fruit and fruit jams than the $\mathrm{HC}$ women. Potato intake accounted for $53-62 \%$ consumption of vegetables, while apples for $58-66 \%$ of fruit eaten in all groups. Cereals and cereal products consumption was $47 \%$ higher in the men than in the women, with respective $56-63 \%$ and $45-49 \%$ contributions of white bread. Minor intakes of chocolates, nuts and seeds were observed in all studied subjects, although the men with CVD were 2-fold more frequent consumers of these foods.

Dietary total antioxidant capacity in the studied groups is shown in Table 4. Mean DTAC in the men with CVD was $6442 \mu \mathrm{mol} \mathrm{TE} /$ person/day and $6066 \mu \mathrm{mol} \mathrm{TE} /$ person/ day in the $\mathrm{HC}$ men, with the highest contribution of tea (34\%), coffee (14\%), apples (9\%), and nuts and seeds (9\%) in the subjects with CVD and tea (38\%), coffee (16\%) and apples $(7 \%)$ in HC (Table 5). Despite lower DTAC in the $\mathrm{HC}$ men, antioxidant capacity of consumed beverages was significantly higher in $\mathrm{HC}$ vs. the men with CVD. Mean DTAC in the women with CVD was significantly higher than in the HC women (6182 vs. $5500 \mu \mathrm{mol} \mathrm{TE} /$ person/ day, respectively) and it was associated with significantly higher antioxidant capacity of consumed fruit and fruit jams in the women with CVD. The highest intakes of antioxidants in the women with CVD and the $\mathrm{HC}$ women were: tea ( 32 vs. $34 \%$ ), coffee (17 vs. $20 \%$ ), apples (10 vs. $8 \%$ ), and strawberries (7 vs. $6 \%$ ).

DTPC in the study groups is presented in Table 6. DTPC in the males with CVD was $1198 \mathrm{mg}$ GAE/ person/day vs. $1114 \mathrm{mg} \mathrm{GAE} /$ person/day in $\mathrm{HC}$, with the highest contribution of tea (24\%), coffee (9\%), cabbage (9), potatoes $(8 \%)$, apples $(8 \%)$ and white bread (6\%) in CVD patients, and tea (27\%), coffee (10\%), potatoes $(10 \%)$, white bread $(8 \%)$ and apples $(7 \%)$ in the $\mathrm{HC}$ subjects (Table 5). DTPC in the females was significantly higher in the subjects with CVD in comparison to HC (1075 vs. $981 \mathrm{mg}$ GAE/person/day, respectively), and was associated with higher consumption of polyphenols from fruit and fruit jams. Predominant sources of polyphenols in the women with CVD and in the HC women were: tea ( 24 vs. $25 \%)$, coffee (12 vs. $13 \%$ ), apples (10 vs. $8 \%$ ), potatoes (6 vs. $8 \%$ ) and cabbage (6 vs. $6 \%$ ).

DTFC in the men with CVD was $212 \mathrm{mg}$ QE/person/ day vs. $202 \mathrm{mg} \mathrm{QE} /$ person/day in HC (Table 7). The males with CVD presented significantly higher consumption of flavonoids from beverages and lower intake of flavonoids from fruit and fruit jams than HC. The main sources of flavonoids both in the men with CVD and in $\mathrm{HC}$ were: tea (29 vs. $32 \%)$, apples (18 vs. $14 \%$ ), cabbage (14 vs. $10 \%)$, coffee (8 vs. $9 \%$ ) and potatoes (6 vs.7\%) (Table 5). Dietary flavonoid intake in the women with CVD was significantly higher as compared to the $\mathrm{HC}$ women, and it was dependent on the higher consumption of flavonoids from fruit and fruit jams. The predominant flavonoid sources in the women with CVD vs. the HC women were: tea ( 28 vs. $29 \%$ ), apples (20 vs. $17 \%)$, coffee (10 vs. $12 \%)$ and cabbage (10 vs. $10 \%)$.

\section{Discussion}

Diets that teem with antioxidants are relevant to body antioxidant status and are essential for prevention and alleviation of oxidative stress-related symptoms [20,21]. Polyphenols and flavonoids, which belong to this group of compounds, are plentiful dietary antioxidants, that may protect against oxidative damage, reducing by this risk of various diseases [22]. Despite this, a number of studies, that estimate flavonoid, polyphenol or antioxidant-rich food intakes is narrow, or the reports 
Table 2 Plant food and beverage intakes in the study groups $(\mathrm{g}[\mathrm{ml}]$ fresh edible mass/person/day)

\begin{tabular}{|c|c|c|c|c|c|c|c|c|c|c|}
\hline \multirow{3}{*}{$\begin{array}{l}\text { Plant food and } \\
\text { beverages }\end{array}$} & \multicolumn{4}{|l|}{ Men } & \multirow[t]{3}{*}{$P$} & \multicolumn{4}{|l|}{ Women } & \multirow[t]{3}{*}{$\mathbf{P}$} \\
\hline & \multicolumn{2}{|c|}{ CVD patients $(n=357)$} & \multicolumn{2}{|c|}{ Healthy control $(n=357)$} & & \multicolumn{2}{|c|}{ CVD patients $(n=286)$} & \multicolumn{2}{|c|}{ Healthy control $(n=286)$} & \\
\hline & Mean $95 \% \mathrm{Cl}$ & $\begin{array}{l}\text { Median 25-75 } \\
\text { percentile }\end{array}$ & Mean 95\% Cl & $\begin{array}{l}\text { Median } 25-75 \\
\text { percentile }\end{array}$ & & Mean $95 \% \mathrm{Cl}$ & $\begin{array}{l}\text { Median 25-75 } \\
\text { percentile }\end{array}$ & Mean $95 \% \mathrm{Cl}$ & $\begin{array}{l}\text { Median } 25-75 \\
\text { percentile }\end{array}$ & \\
\hline$\overline{\text { Beverages }}^{1}$ & $584.3(546-622)$ & $500(400-750)$ & $627.6(589-666)$ & $600(400-800)$ & 0.09 & $528.8(496-562)$ & $500(350-750)$ & $509.0(478-540)$ & $500(250-700)$ & 0.38 \\
\hline tea infusion ${ }^{2}$ & $403.8(373-435)$ & & $421.6(392-451)$ & & & $363.8(335-393)$ & & $341.1(316-366)$ & & \\
\hline coffee infusion ${ }^{3}$ & $119.7(102-137)$ & & $124.4(108-141)$ & & & $138.7(120-158)$ & & $141.1(122-161)$ & & \\
\hline others ${ }^{4}$ & $60.8(41-80)$ & & $81.5(58-105)$ & & & $26.3(15-38)$ & & $26.9(17-37)$ & & \\
\hline Vegetables & $521.2(486-557)$ & $515(266-728)$ & $560.5(526-594)$ & $527(329-729)$ & 0.12 & $415.9(383-449)$ & $386(187-602)$ & $421.9(387-457)$ & $386(190-598)$ & 0.93 \\
\hline potatoes & $307.7(280-336)$ & & $346.1(318-375)$ & & & $218.6(194-244)$ & & $246.9(220-274)$ & & \\
\hline cabbage $^{5}$ & $50.3(41-60)$ & & $46.2(37-56)$ & & & $41.0(33-49)$ & & $37.9(31-45)$ & & \\
\hline tomatoes & $43.1(34-52)$ & & $42.0(34-50)$ & & & $49.4(39-60)$ & & $33.8(25-42)$ & & \\
\hline carrots & $24.0(20-28)$ & & $26.9(22-32)$ & & & $24.1(18-30)$ & & $23.8(19-29)$ & & \\
\hline onions & $15.5(13-18)$ & & $15.2(13-17)$ & & & $11.8(10-14)$ & & $11.9(10-14)$ & & \\
\hline beetroots & $11.8(8-16)$ & & $13.4(9-18)$ & & & $10.0(6-14)$ & & $8.9(5-13)$ & & \\
\hline cauliflower & $4.6(1-8)$ & & $4.6(2-7)$ & & & $8.3(3-13)$ & & $3.3(1-6)$ & & \\
\hline others ${ }^{6}$ & $64.2(56-72)$ & & $66.9(59-73)$ & & & $52.6(46-59)$ & & $55.3(47-63)$ & & \\
\hline Fruit and jams & $194.3(171-217)$ & $140(0-300)$ & $167.4(146-189)$ & $104(0-255)$ & 0.06 & $238.3(208-269)$ & $178(15-328)$ & $181.3(158-205)$ & $150(5-280)$ & 0.02 \\
\hline apples & $129.3(111-147)$ & & $100.6(84-117)$ & & & $138.2(116-160)$ & & $106.1(91-121)$ & & \\
\hline bananas & $7.1(3-11)$ & & $12.2(7-18)$ & & & $11.8(7-17)$ & & $10.9(7-15)$ & & \\
\hline strawberries & $10.6(5-17)$ & & $7.5(3-12)$ & & & $20.8(7-35)$ & & $13.8(5-23)$ & & \\
\hline plums & $8.5(4-13)$ & & $13.6(8-19)$ & & & $11.3(7-16)$ & & $11.7(4-20)$ & & \\
\hline pears & $7.9(3-12)$ & & $6.6(2-11)$ & & & $9.1(3-15)$ & & $3.0(0-6)$ & & \\
\hline citrus fruits $^{7}$ & $8.5(3-14)$ & & $7.4(3-11)$ & & & $12.0(5-19)$ & & $7.6(2-13)$ & & \\
\hline grapes & $5.6(1-10)$ & & $3.1(0.4-6)$ & & & $12.0(5-19)$ & & $9.2(4-14)$ & & \\
\hline sour cherries & $4.6(2-7)$ & & $1.2(0.3-2)$ & & & $5.1(1-9)$ & & $5.2(2-8)$ & & \\
\hline others $^{8}$ & $12.1(9-16)$ & & $15.1(7-23)$ & & & $18.0(11-25)$ & & $13.9(9-18)$ & & \\
\hline Cereal products & $198.8(187-211)$ & $184(128-253)$ & $201.9(188-216)$ & $183(115-261)$ & 0.98 & $138.4(129-148)$ & $122(81-180)$ & $136.5(126-147)$ & $126(72-179)$ & 0.84 \\
\hline white bread & $112.2(101-124)$ & & $128.0(115-141)$ & & & $61.6(53-70)$ & & $66.8(58-76)$ & & \\
\hline others $^{9}$ & 86.6 (77-96) & & 73.9 (63-84) & & & $76.8(68-86)$ & & $69.6(62-78)$ & & \\
\hline Chocolates $^{10}$ & $1.6(0.6-2.7)$ & 0 & $1.2(0.4-2)$ & 0 & 0.69 & $0.7(0.2-1.2)$ & 0 & $0.6(0.1-1.1)$ & 0 & $\overline{0.62}$ \\
\hline Nuts and seeds $^{11}$ & $1.7(0-3.5)$ & 0 & $0.9(0.1-1.7)$ & 0 & 0.99 & $0.7(0-1.5)$ & 0 & $0.6(0-1.4)$ & 0 & $\overline{0.07}$ \\
\hline
\end{tabular}

$\mathrm{n}$ - number; CVD - cardiovascular disease; $\mathrm{Cl}$ - confidence interval; ${ }^{1}$ tea infusion, coffee infusion, drinking chocolate, hot cocoa $-1 \mathrm{~g}$ sample per $100 \mathrm{ml}$ boiling distilled water; ${ }^{2}$ tea infusion: black tea, green tea, red tea, rooibos tea, white tea; ${ }^{3}$ coffee infusion: instant coffee, ground coffee; ${ }^{4}$ others: beer, apple juice, orange juice, red wine, white wine, black currant juice, lemon juice, hot cocoa, drinking chocolate; ${ }^{5}$ cabbage: white, red cabbage and Chinese cabbage; ${ }^{6}$ others: cucumber, parsley roots, leeks, celery roots, fennel, sorrel, chives, red and green pepper, lettuce, radish, tomato paste, ketchup, green beans, beans, peas, button mushrooms; ${ }^{7}$ citrus fruits: oranges, grapefruits, mandarins; ${ }^{8}$ others: sweet cherries, apricots, red currants, nectarines, peaches, kiwi fruits, watermelon, northern cranberries, bilberries, woodland strawberries, lingonberries, raspberries, jams (orange, bilberry, plum, black currant, sour cherry, strawberry, apricot, peach, pineapple); 'others: wheat rolls, wheat four, wholegrain bread, noodles, buckwheat groats, barley groats, extruded rye bread, extruded graham bread, oats, rice; ${ }^{10}$ chocolates: dark, semisweet, milk, white; " nuts and seeds: walnuts, sunflower seeds, pistachios, hazelnuts, peanuts, pumpkin seeds. 
Table 3 Contribution of individual plant foods and beverages to intake of respective categories (\%)

\begin{tabular}{|c|c|c|c|c|}
\hline \multirow{2}{*}{$\begin{array}{l}\text { Plant food and } \\
\text { beverages }\end{array}$} & \multicolumn{2}{|l|}{ Men } & \multicolumn{2}{|l|}{ Women } \\
\hline & $\begin{array}{l}\text { CVD } \\
\text { patients }\end{array}$ & $\begin{array}{l}\text { Healthy } \\
\text { control }\end{array}$ & $\begin{array}{l}\text { CVD } \\
\text { patients }\end{array}$ & $\begin{array}{l}\text { Healthy } \\
\text { control }\end{array}$ \\
\hline Beverages $^{1}$ & 100 & 100 & 100 & 100 \\
\hline tea infusion ${ }^{2}$ & 69 & 67 & 69 & 67 \\
\hline coffee infusion ${ }^{3}$ & 20 & 20 & 27 & 28 \\
\hline others ${ }^{4}$ & 11 & 13 & 4 & 5 \\
\hline Vegetables & 100 & 100 & 100 & 100 \\
\hline potatoes & 59 & 62 & 53 & 59 \\
\hline cabbage $^{5}$ & 10 & 9 & 10 & 9 \\
\hline tomatoes & 9 & 8 & 12 & 8 \\
\hline carrots & 5 & 5 & 6 & 6 \\
\hline onions & 3 & 3 & 3 & 3 \\
\hline beetroots & 3 & 3 & 3 & 3 \\
\hline cauliflower & 1 & 1 & 2 & 1 \\
\hline others $^{6}$ & 13 & 12 & 13 & 14 \\
\hline Fruit and jams & 100 & 100 & 100 & 100 \\
\hline apples & 66 & 60 & 58 & 58 \\
\hline bananas & 4 & 7 & 5 & 6 \\
\hline strawberries & 5 & 4 & 9 & 8 \\
\hline plums & 4 & 8 & 5 & 6 \\
\hline pears & 4 & 4 & 4 & 2 \\
\hline citrus fruits $^{7}$ & 5 & 4 & 5 & 4 \\
\hline grapes & 3 & 2 & 5 & 5 \\
\hline sour cherries & 2 & 1 & 2 & 3 \\
\hline others $^{8}$ & 7 & 10 & 7 & 8 \\
\hline Cereal products & 100 & 100 & 100 & 100 \\
\hline white bread & 56 & 63 & 45 & 49 \\
\hline others $^{9}$ & 44 & 37 & 55 & 51 \\
\hline
\end{tabular}

CVD - cardiovascular disease.

For ${ }^{1-9}$, see Table 2.

on their major dietary sources are limited to some populations.

Previous studies carried out in the US [23] and Spanish [24] populations used the most extensive USDA flavonoid database to estimate intakes of individual flavonoids or used phenol-explorer database [25] to approximate intakes of polyphenols other than the flavonoids. To calculate dietary total antioxidant capacity, some authors [26] has recently used a published USDA database for ORAC (Oxygen Radical Absorbance Capacity) in selected foods. Others [27] developed an antioxidant food database by using FRAP assay. The present study estimates both volume and patterns of dietary total antioxidant consumption together with total polyphenol and flavonoid intakes in the CVD patients. Phenolic contents in foods are influenced by genetic, environmental and processing factors, therefore use of dietary database that contains indigenous plant foods seemed to be more adequate. Therefore, this study uses a self-developed dietary database that contains total antioxidant capacity, polyphenol and flavonoid contents in plant foods [16-19]. For some beverages and plant foods, which were consumed by the participants, but were not included in this database (such as different types of tea), additional analyses were performed.

Flavonoid intakes in our survey (range 177-212 mg $\mathrm{QE} /$ day) are in agreement with some studies conducted in the US population - $190 \mathrm{mg} /$ day [23], but lower compared to the Spanish population - $313 \mathrm{mg} /$ day [24]. Our present findings concerning polyphenol intakes (range 981-1198 mg GAE/day) are comparable to our previous study performed in the general Polish population (range 1031-1172 mg GAE/day) [18], and also with other studies carried out in the French (1193 mg/day) [28], Finnish $(863 \mathrm{mg} / \mathrm{d})$ [29], and Spanish (1171 mg/d) [30] populations, but lower in comparison to some Polish study, which aimed to examine participants from the city of Krakow (1757 mg/day) [31]. For DTAC, results in the current study (range 5500-6442 $\mu \mathrm{mol}$ TE) are similar to a Spanish study $(6014 \mu \mathrm{mol}$ TE analyzed by the FRAP method) [30], but higher in comparison to our previous research conducted in diabetic patients (range 4271$5697 \mu \mathrm{mol}$ TE by the FRAP method) [20].

The present study established that DTAC was significantly higher in the female CVD patients vs. $\mathrm{HC}$, whereas no differences has been found in the men. The differences in the women can be explained by higher fruit intakes in the women with CVD, as well as by naturally high total antioxidant capacity of consumed fruits, which resulted from the total polyphenol and flavonoid contents.

The main contributors to the DTAC, DTPC and DTFC values in all studied groups were: tea, coffee and apples, as well as cabbage, strawberries and potatoes, because of high consumption of these foods in the Polish population $[18,19]$. Surprisingly, despite generally low nut and seed intake in the Polish population, these foods were one of the major contributors to DTAC in the men with CVD. On the contrary, dietary intake in the women with CVD was teeming with apples and strawberries. It is likely that CVD patients paid more attention to adequate nutrition due to CVD diagnosis. A number of studies showed that nuts and strawberries improved antioxidant status in humans, and their consumption was inversely associated with CVD risk and mortality [32-34]. As it has been demonstrated previously nuts and seeds (mainly walnuts) and strawberries were characterized by high antioxidant capacities as well as by high polyphenol contents [17]. Therefore, despite minor nut and seed intakes and moderate seasonal consumption of strawberries, these foods provide essential sources of antioxidants in a diet. Dietary intakes of antioxidants, however, are dependent 
Table 4 Dietary total antioxidant capacity in the study groups ( $\mu \mathrm{mol} \mathrm{TE} / \mathrm{person} / \mathrm{day}$ )

\begin{tabular}{|c|c|c|c|c|c|c|c|c|c|c|}
\hline \multirow{3}{*}{$\begin{array}{l}\text { Plant food and } \\
\text { beverages }\end{array}$} & \multicolumn{4}{|l|}{ Men } & \multirow[t]{3}{*}{$\mathbf{P}$} & \multicolumn{4}{|l|}{ Women } & $\mathbf{P}$ \\
\hline & \multicolumn{2}{|c|}{ CVD patients $(n=357)$} & \multicolumn{2}{|c|}{ Healthy control $(n=357)$} & & \multicolumn{2}{|c|}{ CVD patients $(n=286)$} & \multicolumn{2}{|c|}{ Healthy control $(n=286)$} & \\
\hline & Mean $95 \% \mathrm{Cl}$ & $\begin{array}{l}\text { Median 25-75 } \\
\text { percentile }\end{array}$ & Mean $95 \% \mathrm{Cl}$ & $\begin{array}{l}\text { Median 25-75 } \\
\text { percentile }\end{array}$ & & Mean $95 \% \mathrm{Cl}$ & $\begin{array}{l}\text { Median 25-75 } \\
\text { percentile }\end{array}$ & Mean $95 \% \mathrm{Cl}$ & & \\
\hline Beverages $^{1}$ & 3287 (3080-3493) & $3050(2035-4290)$ & 3537 (3335-3739) & $3300(2200-4683)$ & 0.04 & $3213(3009-3417)$ & $3059(2200-4296)$ & 3081 (2888-3274) & $2753(1933-4125)$ & 0.31 \\
\hline tea infusion ${ }^{2}$ & $2221(2049-2393)$ & & $2319(2156-2482)$ & & & $2001(1841-2161)$ & & 1876(1736-2016) & & \\
\hline coffee infusion ${ }^{3}$ & $925.0(788-1062)$ & & $961.8(837-1087)$ & & & $1072(926-1218)$ & & $1091(940-1241)$ & & \\
\hline others ${ }^{4}$ & 140.6 (97-184) & & $256.5(163-350)$ & & & $140.2(70-210)$ & & $114.9(66-164)$ & & \\
\hline Vegetables & $730.5(655-806)$ & $562(321-888)$ & $729.2(660-798)$ & $578(336-858)$ & 0.79 & $614.3(544-685)$ & $478(265-719)$ & $562.9(501-625)$ & $452(244-741)$ & 0.41 \\
\hline potatoes & $184.6(1680201)$ & & $207.6(191-225)$ & & & $131.2(116-146)$ & & $148.2(132-164)$ & & \\
\hline cabbage $^{5}$ & $161.0(111-212)$ & & $117.7(85-151)$ & & & $112.6(74-151)$ & & $106.1(71-141)$ & & \\
\hline tomatoes & $64.7(51-78)$ & & $63.0(51-76)$ & & & $74.1(58-90)$ & & $50.7(38-63)$ & & \\
\hline carrots & $36.0(30-42)$ & & $40.4(33-47)$ & & & $36.2(27-45)$ & & $35.8(28-43)$ & & \\
\hline onions & $35.7(29-42)$ & & $35.0(30-40)$ & & & $27.2(23-32)$ & & $27.4(23-32)$ & & \\
\hline beetroots & $120.4(79-162)$ & & $137.1(87-187)$ & & & $102.3(57-147)$ & & $90.6(51-131)$ & & \\
\hline cauliflower & $24.7(6-43)$ & & $25.0(10-40)$ & & & $44.8(17-72)$ & & $18.0(5-31)$ & & \\
\hline others $^{6}$ & $103.4(86-120)$ & & $103.3(87-120)$ & & & $85.9(70-101)$ & & $86.1(70-102)$ & & \\
\hline Fruit and jams & 1374(1177-1571) & $726(0-1980)$ & 1105(937-1272) & $644(0-1540)$ & 0.05 & 1865(1490-2240) & $1100(64-2300)$ & $1445(1166-1724)$ & $660(43-1926)$ & 0.03 \\
\hline apples & $568.7(489-649)$ & & $442.7(371-514)$ & & & $608.2(512-704)$ & & 466.7 (399-534) & & \\
\hline bananas & $24.3(11-37)$ & & $41.6(23-60)$ & & & $40.1(22-58)$ & & $37.1(22-52)$ & & \\
\hline strawberries & $235.4(103-367)$ & & $166.2(61-271)$ & & & 460.1 (157-763) & & $306.0(110-502)$ & & \\
\hline plums & $95.5(47-144)$ & & $152.9(93-213)$ & & & $126.1(75-177)$ & & $130.8(39-222)$ & & \\
\hline pears & $18.9(8-29)$ & & $15.8(5-27)$ & & & $21.9(8-36)$ & & $7.1(0-14)$ & & \\
\hline citrus fruits $^{7}$ & $77.7(28-127)$ & & 62.1 (26-98) & & & 103.6 (39-168) & & $61.2(18-104)$ & & \\
\hline grapes & $60.8(13-109)$ & & $33.6(4-63)$ & & & $129.9(52-207)$ & & $99.3(43-155)$ & & \\
\hline sour cherries & $152.5(82-223)$ & & $40.1(11-69)$ & & & $167.1(45-289)$ & & $172.3(71-274)$ & & \\
\hline others $^{8}$ & $140.3(80-200)$ & & $149.8(70-230)$ & & & $207.8(112-304)$ & & $164.3(72-256)$ & & \\
\hline Cereal products & $353.5(328-379)$ & 306 (204-432) & $354.8(327-383)$ & 316 (192-448) & 0.89 & $260.1(233-287)$ & $197(126-310)$ & $246.7(221-273)$ & $200(124-303)$ & 0.74 \\
\hline white bread & $190.8(171-210)$ & & 217.6 (196-239) & & & $104.8(91-119)$ & & 113.6 (99-129) & & \\
\hline others $^{9}$ & 162.7 (139-187) & & $137.1(111-163)$ & & & $155.3(128-182)$ & & 133.1 (109-157) & & \\
\hline Chocolates $^{10}$ & $136.1(42-230)$ & 0 & 78.5 (27-130) & 0 & 0.69 & $65.4(15-115)$ & 0 & $48.1(9-87)$ & 0 & 0.62 \\
\hline Nuts and seeds ${ }^{11}$ & $561.2(0-1306)$ & 0 & $262.1(29-495)$ & 0 & 0.99 & $164.7(0-350)$ & 0 & $116.6(0-281)$ & 0 & 0.74 \\
\hline Total & 6442(5624-7260) & 5676(3926-7156) & 6066(5688-6445) & 5356(4013-7199) & 0.65 & 6182(5714-6651) & 5643(3887-7271) & $5500(5102-5898)$ & 4754(3619-6606) & 0.01 \\
\hline
\end{tabular}

$\mathrm{n}$ - number, $\mathrm{Cl}$ - confidence interval, CVD - cardiovascular disease, TE - Trolox equivalents.

For ${ }^{1-11}$, see Table 2 . 
Table 5 Percentage contribution of the respective categories and individual plant food and beverage items to DTAC, DTPC and DTFC (\%)

\begin{tabular}{|c|c|c|c|c|c|c|c|c|c|c|c|c|}
\hline \multirow{3}{*}{$\begin{array}{l}\text { Plant food and } \\
\text { beverages }\end{array}$} & \multicolumn{4}{|c|}{ DTAC (\% contribution) } & \multicolumn{4}{|c|}{ DTPC (\% contribution) } & \multicolumn{4}{|c|}{ DTFC (\% contribution) } \\
\hline & \multicolumn{2}{|l|}{ Men } & \multicolumn{2}{|l|}{ Women } & \multicolumn{2}{|l|}{ Men } & \multicolumn{2}{|l|}{ Women } & \multicolumn{2}{|l|}{ Men } & \multicolumn{2}{|l|}{ Women } \\
\hline & $\begin{array}{l}\text { CVD } \\
\text { patients }\end{array}$ & $\begin{array}{l}\text { Healthy } \\
\text { control }\end{array}$ & $\begin{array}{l}\text { CVD } \\
\text { patients }\end{array}$ & $\begin{array}{l}\text { Healthy } \\
\text { control }\end{array}$ & $\begin{array}{l}\text { CVD } \\
\text { patients }\end{array}$ & $\begin{array}{l}\text { Healthy } \\
\text { control }\end{array}$ & $\begin{array}{l}\text { CVD } \\
\text { patients }\end{array}$ & $\begin{array}{l}\text { Healthy } \\
\text { control }\end{array}$ & $\begin{array}{l}\text { CVD } \\
\text { patients }\end{array}$ & $\begin{array}{l}\text { Healthy } \\
\text { control }\end{array}$ & $\begin{array}{l}\text { CVD } \\
\text { patients }\end{array}$ & $\begin{array}{l}\text { Healthy } \\
\text { control }\end{array}$ \\
\hline Beverages $^{1}$ & 51 & 58 & 52 & 56 & 35 & 41 & 38 & 40 & 39 & 43 & 40 & 42 \\
\hline tea infusion ${ }^{2}$ & 34 & 38 & 32 & 34 & 24 & 27 & 24 & 25 & 29 & 32 & 28 & 29 \\
\hline coffee infusion ${ }^{3}$ & 14 & 16 & 17 & 20 & 9 & 10 & 12 & 13 & 8 & 9 & 10 & 12 \\
\hline others ${ }^{4}$ & 2 & 4 & 2 & 2 & 2 & 3 & 2 & 2 & 1 & 2 & 2 & 1 \\
\hline Vegetables & 12 & 12 & 10 & 10 & 26 & 25 & 22 & 23 & 30 & 28 & 25 & 26 \\
\hline potatoes & 3 & 3 & 2 & 3 & 8 & 10 & 6 & 8 & 6 & 7 & 4 & 5 \\
\hline cabbage $^{5}$ & 3 & 2 & 2 & 2 & 9 & 5 & 6 & 6 & 14 & 10 & 10 & 10 \\
\hline tomatoes & 1 & 1 & 1 & 1 & 2 & 2 & 3 & 2 & 3 & 2 & 3 & 2 \\
\hline carrots & $<1$ & $<1$ & $<1$ & $<1$ & $<1$ & $<1$ & $<1$ & $<1$ & 1 & 1 & 1 & 1 \\
\hline onions & $<1$ & $<1$ & $<1$ & $<1$ & 1 & 1 & 1 & 1 & 3 & 3 & 2 & 3 \\
\hline beetroots & 2 & 2 & 2 & 2 & 2 & 2 & 2 & 2 & 1 & 2 & 1 & 1 \\
\hline cauliflower & $<1$ & $<1$ & $<1$ & $<1$ & $<1$ & $<1$ & $<1$ & $<1$ & $<1$ & $<1$ & $<1$ & $<1$ \\
\hline others $^{6}$ & 2 & 2 & 1 & 2 & 3 & 4 & 3 & 3 & 3 & 3 & 2 & 3 \\
\hline Fruit and jams & 21 & 18 & 30 & 27 & 19 & 17 & 27 & 23 & 25 & 21 & 31 & 27 \\
\hline apples & 9 & 7 & 10 & 8 & 8 & 7 & 10 & 8 & 18 & 14 & 20 & 17 \\
\hline bananas & $<1$ & $<1$ & $<1$ & $<1$ & $<1$ & 1 & 1 & 1 & $<1$ & $<1$ & $<1$ & $<1$ \\
\hline strawberries & 4 & 3 & 7 & 6 & 2 & 2 & 5 & 3 & 2 & 1 & 3 & 2 \\
\hline plums & 1 & 3 & 2 & 2 & 1 & 2 & 2 & 2 & 1 & 2 & 2 & 2 \\
\hline pears & $<1$ & $<1$ & $<1$ & $<1$ & $<1$ & $<1$ & $<1$ & $<1$ & $<1$ & $<1$ & $<1$ & $<1$ \\
\hline citrus fruits $^{7}$ & 1 & 1 & 2 & 1 & 1 & 1 & 2 & 1 & 1 & 1 & 2 & 1 \\
\hline grapes & 1 & $<1$ & 2 & 2 & $<1$ & $<1$ & 2 & 2 & $<1$ & $<1$ & 1 & 1 \\
\hline sour cherries & 2 & $<1$ & 3 & 3 & 2 & $<1$ & 2 & 3 & $<1$ & $<1$ & 1 & 1 \\
\hline others $^{8}$ & 2 & 2 & 3 & 3 & 2 & 2 & 3 & 2 & $<1$ & 1 & 1 & 1 \\
\hline Cereal products & 5 & 6 & 4 & 4 & 14 & 14 & 11 & 12 & 6 & 6 & 4 & 5 \\
\hline white bread & 3 & 4 & 2 & 2 & 6 & 8 & 4 & 5 & 3 & 4 & 2 & 2 \\
\hline others $^{9}$ & 2 & 2 & 2 & 2 & 7 & 6 & 7 & 7 & 2 & 2 & 2 & 2 \\
\hline Chocolates $^{10}$ & 2 & 1 & 1 & $<1$ & 2 & 1 & 1 & $<1$ & $<1$ & $<1$ & $<1$ & $<1$ \\
\hline Nuts and seeds ${ }^{11}$ & 9 & 5 & 3 & 2 & 4 & 2 & 1 & 1 & $<1$ & $<1$ & $<1$ & $<1$ \\
\hline Total & 100 & 100 & 100 & 100 & 100 & 100 & 100 & 100 & 100 & 100 & 100 & 100 \\
\hline
\end{tabular}

CVD - cardiovascular disease, DTAC - dietary total antioxidant capacity, DTPC - dietary total polyphenol content, DTFC - dietary total flavonoid content. For ${ }^{1-11}$, see Table 2 .

on seasonal variability of consumption, e.g. intake of berry fruits such as strawberries and raspberries in Poles is the highest in the summer period [26]. This research, however, was conducted throughout the year, therefore it recorded virtually essential and representative sources of antioxidants for the studied population.

According to the literature, main contributors to the flavonoid, polyphenol and antioxidant intakes vary in different populations. Major flavonoid sources in the US diet [23], for example were: tea, citrus juices, wine and citrus fruits, whereas apples, red wine, unspecified fruits and oranges in the Spanish diet [24]. As regards to polyphenol intakes, nonalcoholic beverages and fruits were the most important contributors in the French population [28], while coffee and cereals in the Finnish [29], and coffee, oranges, apples, olives, olive oil and red wine by contrast in the Spanish population at a high cardiovascular risk [35]. As to sources of antioxidants, their major contributors in the Norwegian population [36] were: coffee, tea, red wine, blueberries, walnuts, oranges, cinnamon and broccoli, while in the US population [37] they were: tea, dietary supplements, fruits and fruit juices. 
Table 6 Dietary total polyphenol intake in the study groups (mg GAE/person/day)

\begin{tabular}{|c|c|c|c|c|c|c|c|c|c|c|}
\hline \multirow{3}{*}{$\begin{array}{l}\text { Plant food and } \\
\text { beverages }\end{array}$} & \multicolumn{4}{|l|}{ Men } & \multirow[t]{3}{*}{$\mathbf{P}$} & \multicolumn{4}{|l|}{ Women } & \multirow[t]{3}{*}{$\mathbf{P}$} \\
\hline & \multicolumn{2}{|c|}{ CVD patients $(n=357)$} & \multicolumn{2}{|c|}{ Healthy control $(n=357)$} & & \multicolumn{2}{|c|}{ CVD patients $(n=286)$} & \multicolumn{2}{|c|}{ Healthy control $(n=286)$} & \\
\hline & Mean $95 \% \mathrm{Cl}$ & $\begin{array}{l}\text { Median } 25-75 \\
\text { percentile }\end{array}$ & Mean $95 \% \mathrm{Cl}$ & $\begin{array}{l}\text { Median 25-75 } \\
\text { percentile }\end{array}$ & & Mean $95 \% \mathrm{Cl}$ & $\begin{array}{l}\text { Median } 25-75 \\
\text { percentile }\end{array}$ & Mean $95 \% \mathrm{Cl}$ & $\begin{array}{l}25-75 \\
l e\end{array}$ & \\
\hline Beverages $^{1}$ & $421.1(395-447)$ & $388(279-541)$ & $451.9(426-477)$ & $426(284-594)$ & 0.05 & $405.1(380-431)$ & $378(279-541)$ & $389.2(365-413)$ & $355(232-533)$ & 0.35 \\
\hline tea infusion ${ }^{2}$ & $286.7(265-309)$ & & $299.3(278-320)$ & & & $258.3(238-279)$ & & $242.2(224-260)$ & & \\
\hline coffee infusion ${ }^{3}$ & $111.3(95-128)$ & & $115.7(101-131)$ & & & $129.0(111-147)$ & & $131.2(113-149)$ & & \\
\hline others ${ }^{4}$ & $23.1(16-30)$ & & $36.9(25-48)$ & & & $17.8(10-26)$ & & $15.8(10-22)$ & & \\
\hline Vegetables & $322.1(255-389)$ & $228(136-338)$ & $280.8(240-321)$ & $230(151-338)$ & 0.63 & $236.7(184-289)$ & $186(100-255)$ & $228.8(182-276)$ & $179(96-283)$ & 0.65 \\
\hline potatoes & $95.4(87-104)$ & & $107.3(98-116)$ & & & $67.8(60-76)$ & & $76.6(68-85)$ & & \\
\hline cabbage $^{5}$ & $109.7(45-175)$ & & $54.3(17-92)$ & & & $60.7(11-110)$ & & $59.2(15-104)$ & & \\
\hline tomatoes & $25.9(21-31)$ & & $25.2(20-30)$ & & & $29.7(23-36)$ & & $20.3(15-25)$ & & \\
\hline carrots & $8.4(7-10)$ & & $9.4(8-11)$ & & & $8.4(6-11)$ & & $8.3(7-10)$ & & \\
\hline onions & $16.9(14-20)$ & & $16.6(14-19)$ & & & $12.9(11-15)$ & & $13.1(11-15)$ & & \\
\hline beetroots & $21.1(14-28)$ & & $24.1(15-33)$ & & & $18.0(10-26)$ & & $15.9(9-23)$ & & \\
\hline cauliflower & $4.1(1-7)$ & & $4.2(2-7)$ & & & $7.5(3-12)$ & & $3.1(1-5)$ & & \\
\hline others $^{6}$ & $40.4(35-46)$ & & $39.8(35-45)$ & & & $31.8(27-37)$ & & $32.5(28-37)$ & & \\
\hline Fruit and jams & $224.5(196-253)$ & $136(0-348)$ & $187.6(162-214)$ & $115(0-267)$ & 0.06 & $288.6(241-337)$ & $193(11-385)$ & $227.8(189-266)$ & $125(5-299)$ & 0.02 \\
\hline apples & $99.6(85-114)$ & & 77.5 (65-90) & & & $106.4(90-123)$ & & 81.7 (70-94) & & \\
\hline bananas & $7.4(3-11)$ & & $12.7(7-18)$ & & & $12.3(7-18)$ & & $11.3(7-16)$ & & \\
\hline strawberries & $25.5(11-40)$ & & $18.0(7-29)$ & & & $49.7(17-83)$ & & $33.1(12-54)$ & & \\
\hline plums & $16.9(8-25)$ & & $27.1(16-38)$ & & & $22.3(13-31)$ & & $23.1(7-39)$ & & \\
\hline pears & $5.7(3-9)$ & & $4.7(2-8)$ & & & $6.6(2-11)$ & & $2.1(0-4)$ & & \\
\hline citrus fruits $^{7}$ & $12.7(5-21)$ & & $10.5(5-16)$ & & & $17.3(7-28)$ & & $10.4(3-18)$ & & \\
\hline grapes & $9.6(2-17)$ & & $5.3(1-10)$ & & & $20.4(8-33)$ & & $15.6(7-24)$ & & \\
\hline sour cherries & $23.4(13-34)$ & & $6.2(2-11)$ & & & $25.7(7-44)$ & & $26.5(11-42)$ & & \\
\hline others $^{8}$ & $23.8(16-32)$ & & $25.7(13-39)$ & & & $27.8(17-39)$ & & $24.1(13-35)$ & & \\
\hline Cereal products & $161.9(152-172)$ & $146(100-203)$ & $159.1(148-170)$ & $142(91-209)$ & 0.39 & $119.3(110-129)$ & 100 (64-152) & $115.2(106-125)$ & $102(64-147)$ & 0.69 \\
\hline white bread & $76.3(69-84)$ & & 87.1 (78-96) & & & $41.9(36-48)$ & & $45.4(39-51)$ & & \\
\hline others $^{9}$ & $85.6(76-95)$ & & $72.1(62-82)$ & & & $77.4(68-87)$ & & $69.7(61-79)$ & & \\
\hline Chocolates $^{10}$ & $21.5(7-36)$ & 0 & $12.6(4-21)$ & 0 & 0.69 & $10.2(2-18)$ & 0 & $7.7(1-14)$ & 0 & 0.62 \\
\hline Nuts and seeds ${ }^{11}$ & $46.6(0-107)$ & 0 & $22.4(3-41)$ & 0 & 0.99 & $15.1(0-31)$ & 0 & $11.9(0-27)$ & 0 & 0.74 \\
\hline Total & 1198 (1096-1299) & $1034(775-1356)$ & 1114 (1051-1177) & 999 (768-1312) & 0.46 & 1075 (997-1152) & 956 (703-1254) & 981 (909-1052) & $865(644-1117)$ & 0.01 \\
\hline
\end{tabular}

$\mathrm{n}$ - number, $\mathrm{Cl}$ - confidence interval, CVD - cardiovascular disease, GAE - gallic acid equivalents.

For ${ }^{1-11}$, see Table 2. 
Table 7 Dietary total flavonoid intake in the study groups (mg QE/person/day)

\begin{tabular}{|c|c|c|c|c|c|c|c|c|c|c|}
\hline \multirow{3}{*}{$\begin{array}{l}\text { Plant food and } \\
\text { beverages }\end{array}$} & \multicolumn{4}{|l|}{ Men } & \multirow[t]{3}{*}{$\mathbf{P}$} & \multicolumn{4}{|l|}{ Women } & \multirow[t]{3}{*}{$\mathbf{P}$} \\
\hline & \multicolumn{2}{|c|}{ CVD patients $(n=357)$} & \multicolumn{2}{|c|}{ Healthy control $(n=357)$} & & \multicolumn{2}{|c|}{ CVD patients $(n=286)$} & \multicolumn{2}{|c|}{ Healthy control $(n=286)$} & \\
\hline & Mean $95 \% \mathrm{Cl}$ & $\begin{array}{l}\text { Median 25-75 } \\
\text { percentile }\end{array}$ & Mean $95 \% \mathrm{Cl}$ & $\begin{array}{l}\text { Median } 25-75 \\
\text { percentile }\end{array}$ & & Mean 95\% Cl & $\begin{array}{l}\text { Median } 25-75 \\
\text { percentile }\end{array}$ & Mean $95 \% \mathrm{Cl}$ & $\begin{array}{l}\text { Median } 25-75 \\
\text { percentile }\end{array}$ & \\
\hline Beverages $^{1}$ & $82.6(77.4-87.7)$ & $77(56-114)$ & $88.4(83.5-93.3)$ & $77(60-115)$ & 0.04 & $79.2(74.3-84.1)$ & $77(53-107)$ & $75.8(71.2-80.3)$ & $75(41-103)$ & 0.34 \\
\hline tea infusion ${ }^{2}$ & $61.8(57.0-66.6)$ & & $64.5(60.0-69.0)$ & & & $55.7(51.2-60.1)$ & & $52.2(48.3-56.1)$ & & \\
\hline coffee infusion ${ }^{3}$ & $17.7(15.1-20.3)$ & & $18.4(16.0-20.8)$ & & & $20.5(17.7-23.3)$ & & $20.9(18.0-23.8)$ & & \\
\hline others $^{4}$ & $3.1(2.1-4.0)$ & & $5.5(3.5-7.4)$ & & & $3.0(1.6-4.5)$ & & $2.7(1.7-3.7)$ & & \\
\hline Vegetables & $63.8(54.4-73.1)$ & $40(23-65)$ & $57.1(49.7-64.5)$ & $39(25-62)$ & 0.98 & $49.4(41.8-56.9)$ & $31(17-52)$ & $45.3(38.4-52.3)$ & $29(17-48)$ & 0.56 \\
\hline potatoes & $12.0(10.9-13.1)$ & & $13.5(12.4-14.6)$ & & & $8.5(7.5-9.5)$ & & $9.6(8.6-10.7)$ & & \\
\hline cabbage $^{5}$ & $28.8(19.8-37.8)$ & & $20.1(13.0-27.2)$ & & & $19.9(13.1-26.6)$ & & $17.1(10.7-23.4)$ & & \\
\hline tomatoes & $5.3(4.2-6.4)$ & & $5.1(4.1-6.1)$ & & & $6.0(4.8-7.3)$ & & $4.1(3.1-5.1)$ & & \\
\hline carrots & $2.1(1.8-2.5)$ & & $2.4(2.0-2.8)$ & & & $2.1(1.6-2.7)$ & & $2.1(1.7-2.5)$ & & \\
\hline onions & $6.5(5.4-7.6)$ & & $6.4(5.4-7.3)$ & & & $4.9(4.1-5.8)$ & & $5.0(4.2-5.8)$ & & \\
\hline beetroots & $3.0(2.0-4.0)$ & & $3.4(2.2-4.7)$ & & & $2.5(1.4-3.7)$ & & $2.3(1.3-3.3)$ & & \\
\hline cauliflower & $0.3(0.1-0.6)$ & & $0.3(0.1-0.5)$ & & & $0.6(0.2-0.9)$ & & $0.2(0.1-0.4)$ & & \\
\hline others $^{6}$ & $5.8(5.1-6.5)$ & & $5.9(5.2-6.7)$ & & & $4.8(4.1-5.5)$ & & $4.9(4.2-5.7)$ & & \\
\hline Fruit and jams & $52.5(46.2-58.8)$ & $37(0-87)$ & $43.2(37.6-48.9)$ & $30(0-69)$ & 0.03 & $62.6(54.3-70.8)$ & $43(1-88)$ & $47.6(41.3-54.0)$ & $41(1-73)$ & 0.02 \\
\hline apples & $37.4(32.1-42.6)$ & & $29.1(24.4-33.8)$ & & & $39.9(33.6-46.3)$ & & $30.7(26.2-35.1)$ & & \\
\hline bananas & 0.9 (0.4-1.3) & & $1.5(0.8-2.1)$ & & & $1.4(0.8-2.1)$ & & $1.3(0.8-1.8)$ & & \\
\hline strawberries & $3.2(1.4-5.0)$ & & $2.3(0.8-3.7)$ & & & $6.2(2.1-10.4)$ & & $4.2(1.5-6.8)$ & & \\
\hline plums & $2.6(1.3-4.0)$ & & $4.2(2.6-5.9)$ & & & $3.5(2.1-4.9)$ & & $3.6(1.1-6.1)$ & & \\
\hline pears & $1.2(0.6-1.9)$ & & $1.0(0.3-1.8)$ & & & $1.4(0.5-2.4)$ & & $0.5(0-1.0)$ & & \\
\hline citrus fruits ${ }^{7}$ & $2.7(1.0-4.4)$ & & $2.0(0.8-3.2)$ & & & $3.4(1.2-5.6)$ & & $2.0(0.5-3.4)$ & & \\
\hline grapes & $1.1(0.2-2.0)$ & & $0.6(0.1-1.2)$ & & & $2.4(1.0-3.8)$ & & $1.8(0.8-2.9)$ & & \\
\hline sour cherries & $1.7(0.9-2.5)$ & & $0.5(0.1-0.8)$ & & & $1.9(0.5-3.3)$ & & $2.0(0.8-3.1)$ & & \\
\hline others $^{8}$ & $1.7(1.1-2.2)$ & & $2.1(0.9-3.4)$ & & & $2.3(1.4-3.2)$ & & $1.7(1.0-2.4)$ & & \\
\hline Cereal products & $12.0(11.3-12.8)$ & $11(7-16)$ & $12.3(11.4-13.1)$ & $11(7-16)$ & 0.89 & $8.4(7.8-9.1)$ & $7(5-11)$ & $8.1(7.5-8.8)$ & $7(4-11)$ & 0.71 \\
\hline white bread & $7.0(6.2-7.7)$ & & $7.9(7.1-8.7)$ & & & $3.8(3.3-4.3)$ & & $4.1(3.6-4.7)$ & & \\
\hline others $^{9}$ & $5.1(4.4-5.7)$ & & $4.3(3.6-5.1)$ & & & $4.6(4.0-5.3)$ & & $4.0(3.4-4.6)$ & & \\
\hline Chocolates $^{10}$ & $0.4(0.1-0.7)$ & 0 & $0.2(0.1-0.4)$ & 0 & 0.69 & $0.2(0.04-0.3)$ & 0 & $0.1(0.03-0.3)$ & 0 & 0.62 \\
\hline Nuts and seeds ${ }^{11}$ & $0.6(0-1.4)$ & 0 & $0.3(0.1-0.6)$ & 0 & 0.99 & $0.2(0.001-0.4)$ & 0 & $0.2(0-0.5)$ & 0 & 0.74 \\
\hline Total & 212 (199-225) & $190(131-260)$ & $202(191-212)$ & 180 (133-239) & 0.38 & $200(187-213)$ & $178(124-243)$ & 177 (167-187) & $166(116-220)$ & 0.03 \\
\hline
\end{tabular}

$\mathrm{n}$ - number, $\mathrm{Cl}$ - confidence interval, CVD - cardiovascular disease, $\mathrm{QE}$ - quercetine equivalents.

For ${ }^{1-11}$, see Table 2 . 
The authors are aware of some limitations of this research. At first, food intakes in this study have been estimated with the 1-day 24-hour dietary recall method, that does not reflect habitual or long-term food intakes. Twenty-four-hour recall, however, is a common method, which is useful to estimate mean food intakes in large groups of participants and by this it is suitable for contrasting the dietary status of a group with different levels of risk factors of certain diseases [38]. In this study, however, the number of participants was less than 1300 , but taking into account the fact that the sample selection reflected the general adult Polish population, it seemed to be the most suitable for the objectives of this study. One of the limitations of this cross-sectional study is the fact that some patients may have been more likely to die and thus were excluded from this study thereby introducing bias. Subjects excluded in this manner could have had different dietary patterns or food preferences compared with subjects without cardiovascular disease. Finally, this study might have underestimated some polyphenol, flavonoid and antioxidant intakes from a few specific foods, such as spices for example, and it also did not analyze changes during the food preparation.

\section{Conclusions}

This study demonstrates different sources and patterns of antioxidant, polyphenol and flavonoid intakes in male and female patients with CVD. The dietary intakes of antioxidants, polyphenols and flavonoids were higher in the males with CVD as compared to the healthy male individuals, but the differences were not significant. The men with CVD generally consumed more antioxidants, polyphenols and flavonoids from fruits and jams, chocolates, nuts and seeds, but less from beverages. In the women with CVD, however, significantly higher antioxidant, polyphenol and flavonoid intakes from all food categories surveyed were observed as compared to the healthy women. These results demonstrate attempts made by the studied representative samples of Polish men and women with CVD to introduce beneficial modifications to their dietary practices by enhancing intakes of foods that are sources of antioxidants, polyphenols and flavonoids.

\footnotetext{
Abbreviations

1-d 24-h DR: 1-day 24-hour dietary recalls; BMI: Body mass index; CVD: Cardiovascular disease; DTAC: Dietary total antioxidant capacity; DTFC: Dietary total flavonoid content; DTPC: Dietary total polyphenol content; FRAP: Ferric reducing antioxidant power; GAE: Gallic acid equivalents; HC: Healthy controls; HDL: High-density lipoprotein; ORAC: Oxygen radical absorbance capacity; PSM: Propensity score matching technique; QE: Quercetine equivalents; TE: Trolox equivalents.
}

\section{Competing interests}

The authors declare that they have no competing interests.

\section{Authors' contributions}

MEZ conceived and designed the study, conducted the research, analyzed the data and interpreted the results, wrote the manuscript. AMW edited and revised the manuscript. AW provided the data of WOBASZ study. KMT edited the manuscript. WP performed the statistical analysis. All authors read and approved the final version of the manuscript.

\section{Funding sources}

This study was supported by the Polish Ministry of Science and High Education (grant no. 133-17670 P).

\section{Author details}

${ }^{1}$ Department of Food Commodities Science and Technology, Medical University, Szpitalna 37, Bialystok 15-295, Poland. ²Department of Epidemiology, Cardiovascular Disease Prevention and Health Promotion, Institute of Cardiology, Niemodlińska 33, Warsaw 04-635, Poland.

Received: 9 October 2014 Accepted: 27 January 2015

Published online: 15 March 2015

\section{References}

1. Fearon IM, Faux SP. Oxidative stress and cardiovascular disease: novel tools give (free) radical insight. J Mol Cell Cardiol. 2009;47:372-81.

2. Getz GS, Reardon CA. Nutrition and cardiovascular disease. Arterioscler, Thromb, Vasc Biol. 2007;27:2499-506.

3. Osganian SK, Stampfer MJ, Rimm E, Spiegelman D, Manson JE, Willett WC. Dietary carotenoids and risk of coronary artery disease in women. Am J Clin Nutr. 2003;77:1390-9.

4. McCullough ML, Peterson JJ, Patel R, Jacques PF, Shah R, Dwyer JT. Flavonoid intake and cardiovascular disease mortality in a prospective cohort of US adults. Am J Clin Nutr. 2012;95:454-64.

5. Cai H, Harrison DG. Endothelial dysfunction in cardiovascular diseases: the role of oxidant stress. Circ Res. 2000;87:840-4.

6. Manach C, Scalbert A, Morand C, Rémésy C, Jimenez L. Polyphenols: food sources and bioavailability. Am J Clin Nutr. 2004;79:727-47.

7. Zern TL, Wood RJ, Greene C, West KL, Liu Y, Aggarwal D, et al. Grape polyphenols exert a cardioprotective effect in pre- and postmenopausal women by lowering plasma lipids and reducing oxidative stress. J Nutr. 2005;135:1911-7.

8. Jeong YJ, Choi YJ, Kwon HM, Kang SW, Park HS, Lee M, et al. Differential inhibition of oxidized LDL-induced apoptosis in human endothelial cells treated with different flavonoids. Br J Nutr. 2005;93:581-91.

9. Broda G, Rywik S. Multicenter national Polish population health status tests - WOBASZ project with defined problems and treatment goals. Kardiol Pol. 2005;63(6 Suppl 4):601-4 (in Polish).

10. Rywik S, Kupść W, Piotrowski W, Broda G, Piwoński J, Kurjata P, et al. Multicenter national Polish population health status tests - WOBASZ project. Establishment of methods and logistics. Kardiol Pol. 2005;63(6 Suppl 4):605-13 (in Polish).

11. Kostrzewa G, Broda G, Konarzewska M, Krajewki P, Płoski R. Genetic polymorphism of human $Y$ chromosome and risk factors for cardiovascular diseases: a study in WOBASZ cohort. PLoS One. 2013;25(8(7)):e68155.

12. Mosca L, Barrett-Connor E, Wenger NK. Sex/gender differences in cardiovascular disease prevention: what a difference a decade makes. Circulation. 2011;124:2145-54

13. Benzie IFF, Strain JJ. The ferric reducing ability of plasma (FRAP) as a measure of "antioxidant power": The FRAP assay. Anal Biochem. 1996;239:70-6.

14. Singleton $\mathrm{VL}$, Rossi JA. Colorimetry of total phenolics with phosphomolybdic- phosphotungstic acid reagents. Am J Enol Viticult. 1965;16:144-58.

15. Arvouet-Grand A, Vennat B, Pourrat A, Legret P. Standardization of propolis extract and identification of principal constituents. J Pharm Belg. 1994:49:462-8.

16. Zujko ME, Witkowska AM. Antioxidant potential and polyphenol content of selected food. Int J Food Prop. 2011;14:300-8.

17. Zujko ME, Witkowska AM. Antioxidant potential and polyphenol content of beverages, chocolates, nuts and seeds. Int J Food Prop. 2014;17:86-92.

18. Zujko ME, Witkowska AM, Waśkiewicz A, Sygnowska E. Estimation of dietary intake and patterns of polyphenol consumption in Polish adult population. Adv Med Sci. 2012:57:375-84 
19. Zujko ME, Witkowska AM, Waśkiewicz A, Sygnowska E, Mirończuk-Chodakowska I. Estimation of flavonoid intake and antioxidant capacity of the diet of the Polish adult population. Ann Agric Environ Med. 2015; in press.

20. Zujko ME, Witkowska AM, Górska M, Wilk J, Krętowski A. Reduced intake of dietary antioxidants can impair antioxidant status in type 2 diabetes mellitus patients. Pol Arch Med Wewn. 2014;124:599-607.

21. Shema-Didi L, Kristal B, Sela S, Geron R, Ore L. Does pomegranate intake attenuate cardiovascular risk factors in hemodialysis patients? Nutr J. 2014;13:18.

22. Nantz MP, Rowe CA, Muller C, Creasy R, Colee J, Khoo C, et al. Consumption of cranberry polyphenols enhances human $\gamma \delta-T$ cell proliferation and reduces the number of symptoms associated with colds and influenza: a randomized, placebo-controlled intervention study. Nutr J. 2013;12:161.

23. Chun OK, Chung SJ, Song WO. Estimated dietary flavonoid intake and major food sources of U.S. adults. J Nutr. 2007;137:1244-52.

24. Zamora-Ros R, Andres-Lacueva C, Lamuela-Raventós RM, Berenguer T, Jakszyn $P$, Barricarte $A$, et al. Estimation of dietary sources and flavonoid intake in a Spanish adult population (EPIC-Spain). J Am Diet Assoc. 2010;110:390-8.

25. Tresserra-Rimbau A, Rimm EB, Medina-Remón A, Martínez-González MA, de la Torre $\mathrm{R}$, Corella $\mathrm{D}$, et al. Inverse association between habitual polyphenol intake and incidence of cardiovascular events in the PREDIMED study. Nutr Metab Cardiovasc Dis. 2014;24:639-47.

26. Człapka-Matyasik M, Ast K. Total antioxidant capacity and its dietary sources and seasonal variability in diets of women with different physical activity levels. Pol J Food Nutr Sci. 2014;64:267-76.

27. Carlsen MH, Halvorsen BL, Holte K, Bøhn SK, Dragland S, Sampson L, et al. The total antioxidant content of more than 3100 foods, beverages, spices, herbs and supplements used worldwide. Nutr J. 2010;9:3.

28. Perez-Jimenez J, Fezeu L, Touvier M, Arnault N, Manach C, Hercberg S. Dietary intake of 337 polyphenols in French adults. Am J Clin Nutr. 2011;93:1220-8.

29. Ovaskainen ML, Torronen R, Koponen JM, Sinkko H, Hellstrom J, Reinivuo H. Dietary intake and major food sources of polyphenols in Finnish adults. J Nutr. 2008;138:562-6.

30. Saura-Calixto F, Goñi I. Antioxidant capacity of the Spanish Mediterranean diet. Food Chem. 2006;94:442-7.

31. Grosso G, Stepaniak U, Topor-Mądry R, Szafraniec K, Pająk A. Estimated dietary intake and major food sources of polyphenols in the Polish arm of the HAPIEE study. Nutrition. 2014;30:1398-403.

32. Haddad EH, Gaban-Chong N, Oda K, Sabaté J. Effect of a walnut meal on postprandial oxidative stress and antioxidants in healthy individuals. Nutr J. 2014;13:4.

33. Luo C, Zhang Y, Ding Y, Shan Z, Chen S, Yu M, et al. Nut consumption and risk of type 2 diabetes, cardiovascular disease, and all-cause mortality: a systematic review and meta-analysis. Am J Clin Nutr. 2014;100:256-69.

34. Alvarez-Suarez JM, Giampieri F, Tulipani S, Casoli T, Di Stefano G, González-Paramás AM, et al. One-month strawberry-rich anthocyanin supplementation ameliorates cardiovascular risk, oxidative stress markers and platelet activation in humans. J Nutr Biochem. 2014;25:289-94.

35. Tresserra-Rimbau A, Medina-Remón A, Pérez-Jiménez J, Martínez-González MA, Covas MI, Corella D, et al. Dietary intake and major food sources of polyphenols in a Spanish population at high cardiovascular risk: the PREDIMED study. Nutr Meta Cardiovasc Dis. 2013;23:953-9.

36. Qureshi SA, Lund AC, Veierød MB, Carlsen MH, Blomhoff R, Andersen LF, et al. Food items contributing most to variation in antioxidant intake; a cross-sectional study among Norwegian women. BMC Public Health. 2014;14:45.

37. Yang M, Chung SJ, Chung CE, Kim DO, Song WO, Koo SI, et al. Estimation of total antioxidant capacity from diet and supplements in US adults. Br J Nutr. 2011;106:254-63.

38. Chun OK, Floegel A, Chung SJ, Chung CE, Song WO, Koo SI. Estimation of antioxidant intakes from diet and supplements in U.S. adults. J Nutr. 2010;140:317-24.

\section{Submit your next manuscript to BioMed Central and take full advantage of:}

- Convenient online submission

- Thorough peer review

- No space constraints or color figure charges

- Immediate publication on acceptance

- Inclusion in PubMed, CAS, Scopus and Google Scholar

- Research which is freely available for redistribution 